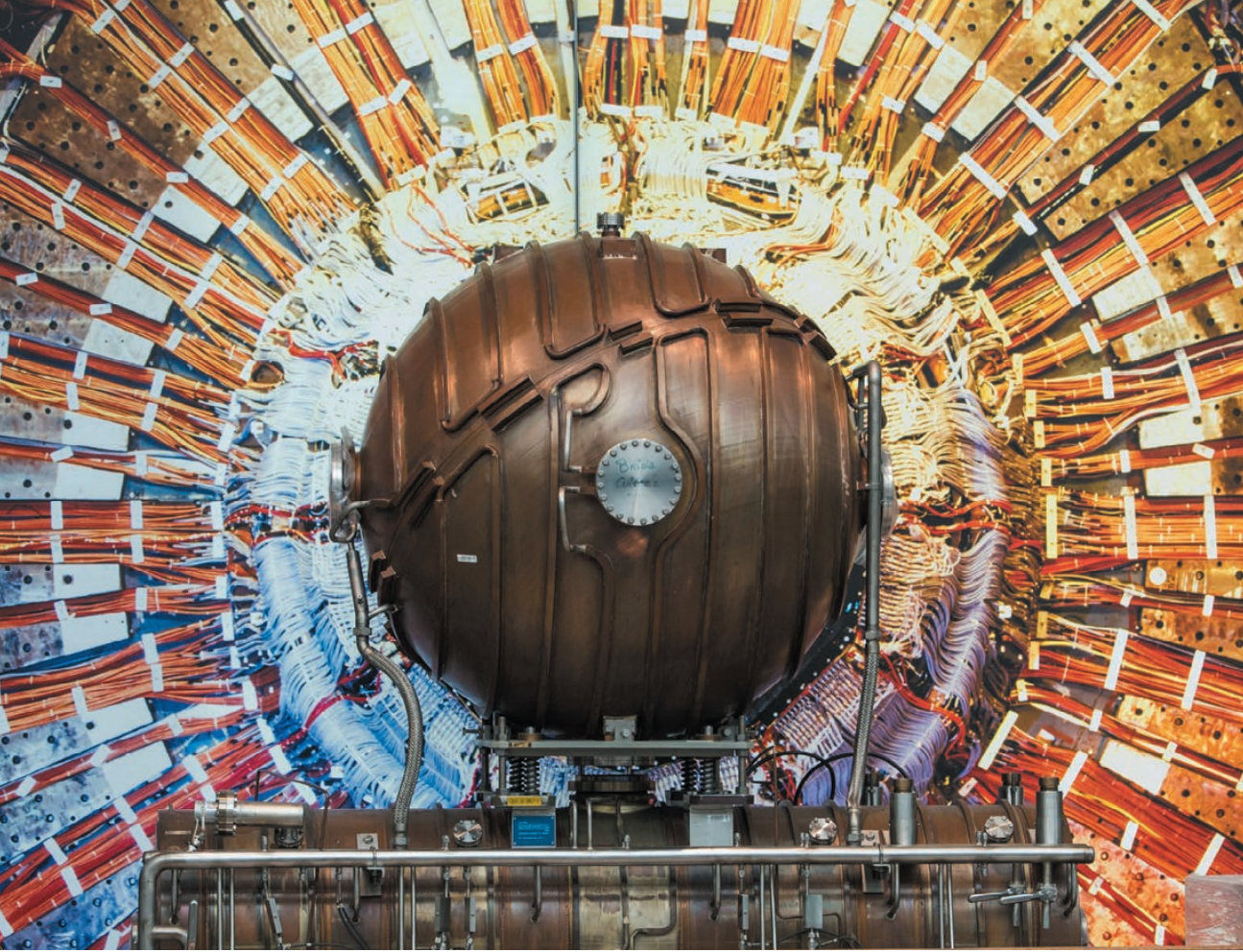

Part of CERN's Large Electron-Positron Collider, on display at the National Museum of Scotland.

MUSEUMS

\title{
Workshop of the world
}

\section{Colin Macilwain talks to the curators of the National Museum of Scotland on the eve of a grand expansion.}

\section{$\mathrm{T}$} he afterlife of Dolly the sheep will take an exciting turn next month: the clone is the first attraction of a new, permanent exhibition at the National Museum of Scotland (NMS). Dolly, who died in 2003 and survives in taxidermied splendour, will greet visitors at the entrance to a grand atrium housing ten refurbished science, technology and design galleries in the Victorian building, which sits beside the University of Edinburgh.

Since Dolly's leap to fame (see go.nature. com/1ujdd4k), the anticipated commercial bonanza in cloning has not occurred. Nevertheless, the bovid is part of a rip-roaring story of how a nation of 5 million people helped to forge the modern age.

"Scotland was the workshop of the world," explains Klaus Staubermann, a science historian and principal curator of technology at the NMS. He alludes to the turn of the last century, when Glasgow's Clydeside hosted as much as one-quarter of global shipbuilding and locomotive production. But he brushes off any suggestion that the transformation from powerhouse to tourist attraction is a metaphor for Scotland's recent history that runs too close to the bone. "The Scots have always had this ability to reinvent themselves," Staubermann says, noting the 'Silicon Glen' of the 1980s. Here, much of Europe's computer hardware was assembled. More recent, if scattered, successes have emerged in computer gaming National Museum (Grand Theft Auto of Scotland gallery originated here) and opening biomedical science.

8 July 2016

The range of exhibEdinburgh, UK. its being installed does justice to Staubermann's grand narrative. There is an accelerating ring from the disused Large Electron-Positron Collider at CERN (Peter Higgs, namesake of the boson, is at the University of Edinburgh). There's the story of Glasgow pharmacologist and Nobel laureate James Black, who had a central role in developing beta blockers. And there will be a stunning array of electrical and mechanical engineering, from the world's oldest Stirling engine to the tip of a modern wind-turbine blade.

The unifying theme of the six new science and technology galleries is to follow scientific concepts through to technology and production. The museum's wider collection reflects diligent hoarding of bits and pieces from the Industrial Revolution. "Many Scots have held on to their working machinery," says Staubermann. His research

A model of a heat engine made by Robert Stirling in 1816. includes the history of the machine-tool industry, due to feature in a manufacturing hall. (Europe's first numerically controlled machine tool was built by electronics firm Ferranti in Edinburgh in the 1960s.)

The NMS is Britain's most popular museum outside London, with 1.6 million visitors last year. It has enjoyed steady public and private support, while many museums globally are suffering from cuts. The $£ 14$-million (US\$20-million) refurbishment is supported by the UK national lottery, biomedical charity the Wellcome Trust, the Scottish government and private donors. It is part of a $£ 80$-million, 15 -year 'masterplan' to transform the premises, built in 1866 .

Touring the exhibition areas last month, surrounded by workers assembling displays, I saw how technology is transforming the craft of exhibiting itself. For example, layers of interactivity allow visitors to delve as deep as they like. But there will also be olderschool approaches on display. "Whenever I tell a taxi driver what I'm doing, the first thing they want to know is if there'll be plenty of buttons to push," says Staubermann.

The museum's first director, George Wilson, was a professor of technology at the University of Edinburgh, and the institutions remain closely linked. Most museum curators teach at the university, and many are involved in joint research projects.

Right now, the priority is the logistics of installing some 3,000 objects - threequarters on public display for the first time — in time for the 8 July opening. Elsa Cox, curator of the energy hall, Energise, has just collected a control console from the decommissioned Murchison oil platform in the North Sea. One of the challenges, she says, is getting industrial contributors to take her deadlines seriously.

Energise exhibits will include an early prototype of Salter's duck - a key device in the history of wave power - and the switch that connected the now-defunct Dounreay fast breeder reactor in Caithness to the grid. Visitors will get the chance to power a city for a day, Cox says, learning about the trade-offs between different sources of energy.

The display won't take sides on the heated argument between the Scottish government, which backs wind-power, and the

government of Britain at large, which has cut support for renewables and wants to increase nuclear capacity. "The Scottish government funds us," says museum spokesman Bruce Blacklaw. "It doesn't govern us."

Colin Macilwain is a sciencepolicy journalist, based in Edinburgh, and editor of the policy newsletter Research Europe. e-mail:cfmworldview@googlemail. com 